\title{
Influence of a Deficiency of the Second Component of Complement on the Bactericidal
}

\section{Activity of Neutrophils In Vitro}

\author{
John E. Repine, C. C. Clawson, and Peter S. Friend \\ From the Pulmonary and the Nephrology Sections of the Department of Medicine, and the \\ Hematology Section of the Department of Pediatrics, University of Minnesota Health Sciences \\ Center, Minneapolis, Minnesota 55455
}

\begin{abstract}
A B S T RAC T Serum from three patients with a complete, selective deficiency of the second component of complement (C2) did not promote optimal killing of Staphylococcus aureus, $502 \mathrm{~A}$ by neutrophilic polymorphonuclear leukocytes (PMN) in vitro. The addition of $\mathrm{C} 2$ reagent or the presence of heat-stable opsonin in the C2-deficient serum corrected the defective killing of $S$. aureus that was observed with patient or control PMN. PMN from the patients or control subjects killed bacteria with equal efficiency under conditions of optimal opsonization (normal pooled serum). However, twice-washed control PMN were better than patient PMN in killing $S$. aureus under circumstances of suboptimal opsonization (C2deficient serum, heated C2-deficient serum, heated normal pooled serum, or no replacement of serum). The latter finding was due to residual C2 on the surface of twice-washed control cells. As repeated washings of eontrol PMN progressively removed cell-associated C2, the staphylocidal effectiveness of the control PMN decreased to the level of patient PMN. In contrast to the findings with $S$. aureus, triply-washed PMN from patients or controls killed normal numbers of Escherichia coli, 0N2, in C2-deficient serum.
\end{abstract}

\section{INTRODUCTION}

Neutrophilic polymorphonuclear leukocytes (PMN) ${ }^{1}$ play a crucial role in host defense by engulfing and

Dr. Repine is an Established Investigator of the American Heart Association.

Received for publication 6 October 1976 and in revised form 22 December 1976.

${ }^{1}$ Abbreviations used in this paper: C2, second component of human complement; HBSS, Hanks' balanced salt solution; HSO, heat-stable opsonin; PMN, neutrophilic polymorphonuclear leukocytes. killing invading microorganisms. Opsonins participate in the process by facilitating ingestion of bacteria by PMN. Opsonic substances in serum include heatlabile components (primarily complement) and heatstable factors such as antibody. The specific requirements for these agents in providing optimal phagocytosis and killing of bacteria are not completely understood (1-9). Considerable controversy exists regarding the necessity for early components of complement for the opsonization of bacteria (1118). The basis for the conflicting evidence has usually been attributed to methodological differences. Published studies have employed a wide variety of phagocytic cells, test particles, and assay systems (2-17). A comparison of the findings from these studies indicates that these modifications of experimental design have influenced the results. Two important variables, however, have not been evaluated rigorously for their influence on phagocytosis and killing. These are the initial ratio of bacteria per neutrophil and the trace amounts of serum components remaining on the surface of washed PMN $(7,8)$.

In the present investigation, cells and sera from three patients with a selective, complete deficiency of the second component of human complement (C2) were used to explore the role of $\mathrm{C} 2$ in opsonization. These experiments also provided an effective avenue for a detailed evaluation of the above two variables in experimental design. The results indicate that $\mathrm{C} 2$ is necessary for optimal bactericidal activity of normal PMN against Staphylococcus aureus, 502A but not against Escherichia coli, 0 N2. The findings also demonstrate the importance of the initial ratio of bacteria per neutrophil and of residual serum components on the PMN surface in the design and interpretation of such experiments. 


\section{METHODS}

This investigation was approved by the Human Volunteers Committee of the University of Minnesota. Blood was donated by three patients whose sera were selectively deficient in $\mathrm{C} 2$, and 10 normal control subjects, none of whom had infections at the time of study. The clinical diagnoses of the three patients were chronic vasculitis, systemic lupus erythematosus, and discoid lupus erythematosus, respectively. Clinical features of the first two patients have been reported in detail previously $(16,17,19)$ and the third patient will be the subject of the subsequent case report.

Sera from the patients and normal subjects were obtained by venipuncture, allowed to clot on ice, rimmed, recovered by centrifugation, and then frozen in aliquots at $-70^{\circ} \mathrm{C}$ for not more than 2 mo. Sera from five normal subjects were pooled but each patient's serum was studied individually. Complement components were measured using functional hemolytic and radial immunodiffusion assays (20-22). Complement profiles of fresh serum were comparable to serum which was frozen and thawed once before use. For some experiments total measurable hemolytic activity was destroyed by heating at $56^{\circ} \mathrm{C}$ for $30 \mathrm{~min}$. In other studies the assayable hemolytic activity of C2-deficient serum was restored by the addition of $2,500 \mathrm{U}$ of $\mathrm{C} 2$ reagent (Cordis Laboratories, Miami, Fla.). To characterize the purity of this $\mathrm{C} 2$ reagent, the following studies were performed: purified C2 was isolated from the diisopropyl fluorophosphate-treated pseudoglobulin fraction of human serum by carboxymethylcellulose chromatography and Pevikon block electrophoresis (Mercer Consolidated Corp., Yonkers, N. Y.) (23). Fractions containing C2 activity were pooled, concentrated, and then injected in complete Freund's adjuvant into rabbits. Samples of blood from rabbits were applied to a Sepharose-4B immunoadsorbent column (Pharmacia Fine Chemicals, Piscatawa, N. J.) comprised of C2-deficient human serum to purify the antiserum. Monospecificity of the $\mathrm{C} 2$ antiserum was verified by a reaction of complete identity with a reference C2 antiserum (kindly supplied by Dr. Margaret Polley, Cornell University) in immunodiffusion against purified C2, by the presence of a single precipitin line against whole human serum in immunoelectrophoresis, and by the absence of a precipitin line in immunodiffusion against the sera of the three individuals totally deficient for C2. Double diffusion Ouchterlony analysis using normal serum, C2 reagent, and C2 antiserum demonstrated that the $\mathrm{C} 2$ antiserum reacted only with C2 (Fig. 1).

Neutrophils and bacteria were prepared (24) and bactericidal activity was measured using methods previously described in detail (25). Briefly, $4 \times 10^{6}$ washed PMN from a patient or normal subject were combined with washed, stationary phase S. aureus, $502 A$ or $E$. coli, ON2 adjusted to yield ratios of 1.25 or 50 bacteria per neutrophil in $1.0 \mathrm{ml}$ Hanks' balanced salt solution (HBSS) with or without a known percentage of serum. Microsamples of the test mixtures were taken immediately and after incubation for $60 \mathrm{~min}$ at $37^{\circ} \mathrm{C}$. The samples were diluted, osmotically lysed, sonicated, and then plated in agar. After a 48-h period of growth, the number of bacterial colonies on each plate was counted using an automatic colony counter (3M Co. St. Paul, Minn., model 620). Counts at 0 and $60 \mathrm{~min}$ were used to calculate the observed initial ratio of bacteria per neutrophil and the percentage of the initial bacterial inoculum which was killed. Each determination is the average of triplicate samplings from duplicate tubes. Controls to determine the rate of bacterial growth

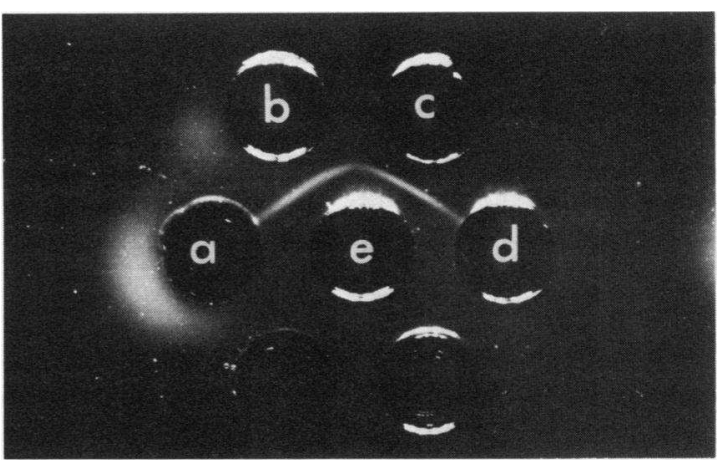

Figure 1 Double diffusion Ouchterlony analysis demonstrated that the $\mathrm{C} 2$ antiserum reacts only with purified C2: C2-deficient serum $(a)$, normal human serum $(b)$, Cordis C2 reagent $(c)$, veronal buffer $(d)$, and rabbit anti-human C2 (e).

and (or) the bactericidal effect of serum were run in parallel with each test.

The standard preparation of PMN for these studies consisted of two washes with HBSS and resuspension in a third aliquot of HBSS. The cells were separated from serum and the HBSS washes by careful decantation after centrifugation at $140 \mathrm{~g}$ for $12 \mathrm{~min}$ at room temperature. In one group of experiments, matched samples of PMN were tested for bactericidal capacity after one to four washes. In another group of studies, PMN were similarly washed using glucosegelatin-veronal buffer with calcium and magnesium. The undiluted supernates from these latter washes were tested for C2 activity by standard hemolytic and modified rat assays $(21,26)$. Effective molecules of C2 per milliliter, and microgram quantities of $\mathrm{C} 2$ protein per milliliter were calculated by previously described methods $(27,28)$.

\section{RESULTS}

In this group of studies, a carefully controlled assay of PMN bactericidal function was used to examine the opsonic potency of sera from C2-deficient patients and control subjects. The details of this method have been presented previously and form the basis for the following experiments (25). The method relies on the bacteria being in lag-phase during the period of incubation with PMN. This was assured by running with each experiment a pair of control tubes which contained all components of the test mixture including serum but excluding the PMN. These serum control tubes were sampled to determine the degree of bacterial replication and (or) possible bactericidal action of the media. The bacterial counts in the control tubes for the following experiments increased $18 \pm 8 \%$ (SD) from the initial inoculum over the 60 min incubation for $S$. aureus and $35 \pm 16 \%$ for $E$. coli. Supernates removed from PMN-S. aureus mixtures after incubation were not bactericidal.

The levels of complement components in the sera of the three patients were all normal except for C2 which was undetectable in all three (Table I).

Bactericidal Activity in C2 Deficiency 
TABLE I

Serum Complement Levels of Three C2-Deficient Patients

\begin{tabular}{|c|c|c|c|c|c|}
\hline \multicolumn{3}{|c|}{ Hemolytic titers: CH50 U/ml } & \multicolumn{3}{|c|}{ Immunodiffusion } \\
\hline Assay & Normal subjects* & Patients $\ddagger$ & Assay & Normal subjects* & Patients $\$$ \\
\hline $\mathrm{CH} 50$ & $23-45$ & 0 & $\mathrm{Clq}$ & $55-123 \mu \mathrm{g} / \mathrm{ml}$ & $123-183$ \\
\hline $\mathrm{Cl}$ & $126,000-369,000$ & $236-297,000$ & $\mathrm{C} 4$ & $57-329 \%$ ref. & $124-192$ \\
\hline $\mathrm{C} 4$ & $48,700-197,000$ & $77-99,000$ & $\mathrm{C} 2$ & Present & Undetected \\
\hline $\mathrm{C} 2$ & $1,353-2,543$ & $<50$ & C3 & $83-248 \mathrm{mg} / 100 \mathrm{ml}$ & $124-192$ \\
\hline \multirow[t]{2}{*}{ C3-9 } & $270-552$ & $704-869$ & Properdin & $53-161 \%$ ref. & $108-158$ \\
\hline & & & Factor B & $20-48 \mu \mathrm{gN} / \mathrm{ml}$ & $24-42$ \\
\hline
\end{tabular}

* $95 \%$ confidence limits.

† Range.

The following experiments were designed to provide answers to two basic questions: first, what is the intrinsic bactericidal capability of the PMN from the three patients with C2 deficiency? Second, what is the influence of $\mathrm{C} 2$ on the total bactericidal process of normal PMN? The exigencies of fully defining the techniques necessitate the following detailed presentation. The results obtained with PMN and (or) serum from each patient were similar; therefore the data are combined for clarity.

Influence of varied serum concentrations on initial ratios of bacteria per neutrophil on bactericidal activity. To determine the minimal amount of serum replacement necessary for optimal opsonization and killing of $S$. aureus by twice-washed control PMN, phagocytic tests were performed at increasing serum concentrations and with two multiples of bacteria per neutrophil. As shown in Fig. 2, the minimal amount of serum replacement necessary for maximal bactericidal activity was dependent on the initial number of $S$. aureus. Addition of $4 \%$ normal pooled serum to

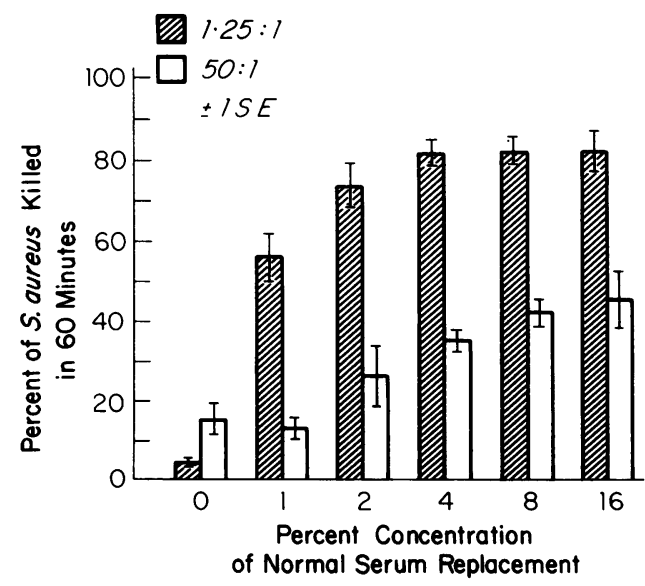

FIGURE 2 Effect of normal serum concentration on the percentage of $S$. aureus killed by twice-washed control PMN at $\mathbf{1 . 2 5}$ or $\mathbf{5 0}$ bacteria per cell. twice-washed cells provided maximal staphylocidal activity at 1.25 bacteria per neutrophil. The optimal concentration of replacement serum at 50:1 was $8 \%$. Parallel studies indicated that the serum requirements for $E$. coli were similar.

Effect of C2 deficiency on bactericidal activity against $S$. aureus. With the above findings for control PMN and normal pooled serum as background, a comparison was made with the bactericidal function of PMN and sera from C2-deficient patients. The results of these studies conducted at both 1.25 and $50 \mathrm{~S}$. aureus per neutrophil are presented in Table II. In all of these experiments, PMN were twicewashed ans resuspended in HBSS. Where serum was added to the phagocytic system, $4 \%$ was used for all 1.25:1 studies and $8 \%$ was used in the 50:1 studies. These levels were chosen to provide the minimum concentration of serum consistent with optimal opsonization (Fig. 2). PMN from the patients were tested with autologous serum where the tables indicate replacement with C2-deficient serum.

At the ratio of 1.25 bacteria per neutrophil, twicewashed control PMN killed only about half the number of $S$. aureus in C2-deficient sera as in normal pooled serum. However, C2-deficient serum supported a 10fold increase in killing of $S$. aureus by PMN over that seen without replacement of serum. When the C2deficient sera were reconstituted with $2,500 \mathrm{U}$ of $\mathrm{C} 2$ reagent per milliliter, the bactericidal capacity of the control cells returned to normal. In contrast, at 50:1 C2-deficient sera supported bactericidal activity of control PMN as well as normal pooled serum. Addition of purified C2 did not significantly increase bactericidal activity at 50:1.

The specific role of $\mathrm{C} 2$ in the opsonization process was confirmed by studies using a well-characterized, purified C2 antiserum. Normal serum treated with monospecific C2 antiserum did not promote optimal opsonization and killing of S. aureus by PMN. Furthermore, addition of $\mathrm{C} 2$ reagent that had been pretreated with C2 antiserum to the patient's C2-deficient serum 
TABLE II

Comparison of Bactericidal Activity of PMN and Sera from Control Subjects and Patients with C2 Deficiency

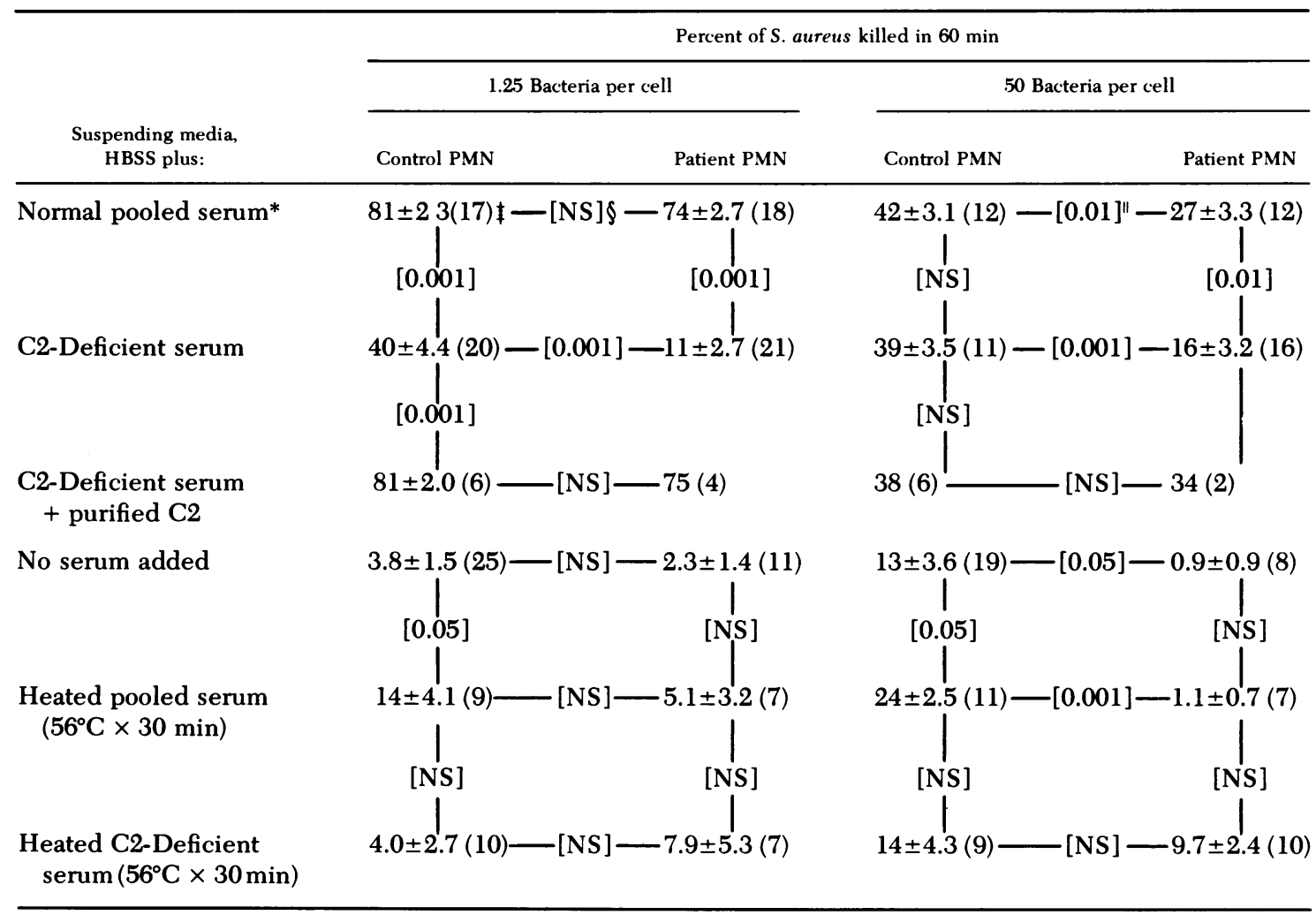

* All serum levels for $1.25: 1$ were $4 \%$ and for $50: 1$ were $8 \%$.

$\ddagger$ Mean $\pm \mathrm{SE},(n)$.

$\S[P$ values, NS $>0.05]$.

"See text for clarification.

and control PMN did not correct the observed defect in bactericidal activity. Improved bactericidal activity was achieved by adding sufficient $\mathrm{C} 2$ reagent to the aforementioned test mixtures.

Bactericidal activity of PMN from C2-deficient patients. Parallel examinations of the function of twice-washed PMN from the three C2-deficient patients were made (Table II). At the lower bacterial ratio, the patients' cells had significantly depressed bactericidal function only with autologous serum. The depressed bactericidal activity was not improved by increasing the percentage of serum added (Fig. 3). After the C2-deficient sera were reconstituted with purified C2 reagent, the function of PMN from the patients was normal (Table II). In normal pooled serum at the low ratio of $S$. aureus, the patients' PMN killed a normal percentage of the bacteria.

When the patients' PMN were challenged with $50 \mathrm{~S}$. aureus per cell, a similar pattern of bactericidal activity was noted. Killing of $S$. aureus was significantly depressed for each of the three populations of these PMN when tested with autologous serum.
Again reconstitution of the C2-deficient sera with C2 reagent restored bactericidal function to normal. The mean percentage of $S$. aureus killed $(27.2 \pm 3.3$, Table II) at the high ratio by patients' PMN in normal pooled serum requires clarification. In this and other studies, normal PMN tested at 50:1 have killed $42 \pm 20$ (2 SD) or from 22 to $62 \%$ of the $S$. aureus presented. None of the three mean values for killing of bacteria of PMN from the individual patients fell below these limits although as a group they tended to be in the lower normal region. Therefore, taken in toto, these several examinations must be interpreted to reveal no intrinsic defect in the ability of the patients' PMN to kill S. aureus in vitro.

Results of studies without added serum, with heated pooled serum, or with heated C2-deficient sera are also given in Table II. Addition of heated control serum produced slight increases $(P \leq 0.05)$ in killing of $S$. aureus by control cells over serum-free levels at both 1.25:1 and 50:1. This increase resulting from the addition of heated pooled serum was not seen with patients' cells. In contrast, at both ratios, heated 


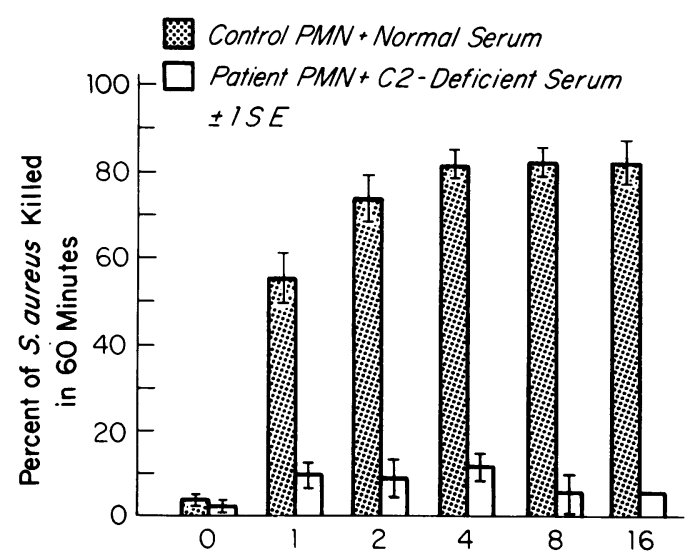

Percent Concentration of Serum Replacement

FIGURE 3 Effect of serum concentration on the percentage of $S$. aureus killed by combinations of control PMN with normal serum or patient PMN with $\mathrm{C} 2$-deficient serum at 1.25 bacteria per cell.

C2-deficient sera supported no more killing of bacteria by PMN from controls or patients than when no serum was replaced in the system. This suggests that heat-stable components present in normal serum interacted differently with twice-washed control cells than with the patients' washed PMN. The reason for this is explained by the following set of experiments.

Influence of trace amounts of serum components remaining on the surface of PMN from control subjects. The studies reported above were all carried out with PMN prepared by a standard doublewashing procedure. Analysis of the data suggested that some of the findings could be explained by residual complement components on the surface of the twice-

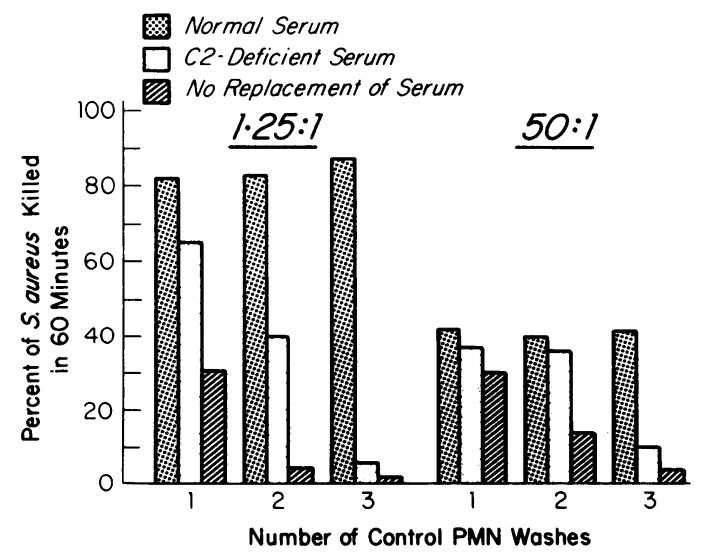

Figure 4 Effect of the number of times control PMN were washed on the percentage of $S$. aureus killed with normal serum replacement, with $\mathrm{C} 2$-deficient serum, or with no serum. Initial bacteria to neutrophil ratios were 1.25: 1 and 50:1. washed neutrophils. These were principally the observations that the patients' PMN, although having normal bactericidal capacity under conditions of optimal opsonization, killed fewer S. aureus than control PMN under suboptimal opsonic conditions (Table II).

To evaluate this possibility, control PMN were tested for bactericidal function after each of a series of four washes with HBSS (Fig. 4). The PMN were fully viable after each wash and showed stable levels of bactericidal activity at both ratios when the final media contained the appropriate concentration of normal pooled serum (Fig. 4). If C2-deficient serum was used for replacement in the incubation media for either test ratio, the killing of $S$. aureus fell to less than $10 \%$ when control PMN had been triply-washed. These levels are comparable to the low degree of killing of bacteria shown above (Table II) when the patients' PMN were tested with autologous C2-deficient sera. Further, the levels of killing by control cells after the third wash were not significantly higher with C2-deficient serum than without replacement of serum. Results of bactericidal assays after a fourth wash were all comparable to those after the third wash; therefore the effect of further washes was not studied. These observations indicate that the discrepancies between bactericidal functions of twicewashed PMN from controls and patients under suboptimal conditions of opsonization were due to a residual serum factor associated with the control cells. This factor may be presumed to be $\mathrm{C} 2$ since this is the only identifiable variable between control and patient cells, and purified C2 provided full correction of function for the patients' PMN.

When the control cells were given a third wash (Fig. 4), the bactericidal capacity in the face of a 50:1 challenge without added serum fell to less than 5\%. This latter value was not a significantly higher level of bactericidal activity than at 1.25:1. These findings indicate the importance of opsonic factors associated

TABLE III

Concentration of $\mathrm{C2}$ in the Supernates from Washes of Control PMN

\begin{tabular}{|c|c|c|c|c|}
\hline & \multicolumn{4}{|c|}{ No. of washes } \\
\hline & 1 & 2 & 3 & 4 \\
\hline Hemolytic, $U / m l^{*}$ & 14,500 & 390 & 9 & 5 \\
\hline Effective molecules $\left(\times 10^{8}\right)$ & 12,800 & 279 & 6 & 2 \\
\hline $\begin{array}{l}\text { Approximate serum content } \\
\text { of } \mathrm{C} 2 / \mathrm{ml}, \mu \mathrm{g} / \mathrm{ml}\end{array}$ & 10 & 0.22 & 0.005 & 0.002 \\
\hline
\end{tabular}

* Normal pooled serum had a C2 level of 30,000 hemolytic $\mathrm{U} / \mathrm{ml}$. 
TABLE IV

Effect of HSO in C2-Deficient Serum on the Bactericidal Activity of Twice-Washed Control PMN

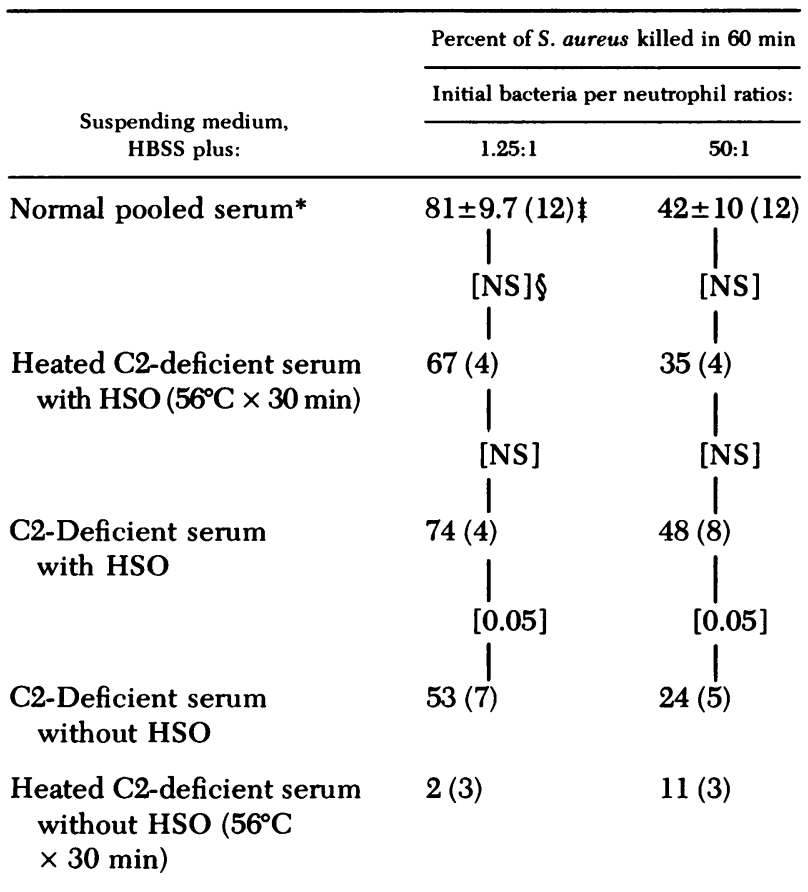

* Serum replacement at $4 \%$ for $1.25: 1$ and $8 \%$ for $50: 1$.

$\$$ Mean \pm 1 SD $(n)$.

$\S[P$ values, NS $>0.05]$.

with the cell surface in the assessment of bactericidal function.

Supernates from the sequential washes of the control cells were tested for C2 activity using a standard hemolytic assay and the more sensitive modified rat assay (Table III). C2 activity was present in significant levels in the third supernate by both assay procedures. This represents the $\mathrm{C} 2$ which could be removed from twice-washed cells by a third HBSS wash. Therefore, at least this amount of C2 remained with the standard twice-washed cells during the majority of the bactericidal assays reported here.

A fourth wash was introduced in an attempt to remove any remaining activity from the triply-washed cells which had shown minimal bactericidal function in the absence of serum replacement. The fourth supernate contained considerably less C2 activity than the first three. This indicated that the first three washes had removed the major portion of cellassociated C2 and correlated well with the functional results in Fig. 4.

Effect of C2-deficient serum containing a heatstable opsonin on the bactericidal activity of control neutrophils. During the period of evaluation, one C2deficient patient developed a heat-stable opsonin
(HSO) in his serum. Experiments were performed to compare this patient's initial serum which was free of HSO and the subsequent serum sample which contained the HSO. At a ratio of $1.25 \mathrm{~S}$. aureus per neutrophil, the presence of HSO corrected the bactericidal activity of twice-washed control PMN with C2-deficient serum (Table IV). At the 50:1 challenge, control PMN killed twice as many S. aureus with C2deficient serum which contained HSO as with C2deficient serum which lacked HSO (48 vs. $24 \%$ ); although both values were within the normal range. The results indicate that the HSO overcame the depressed opsonic activity resulting from the absence of C2 in this patient's serum.

Effect of C2 deficiency on bactericidal activity against $E$. coli. The bactericidal activities of PMN and opsonic effectiveness of sera from normal subjects and a patient (16) with C2-deficiency were compared using E. coli (Table V). All of the studies were performed with triply-washed $\mathrm{PMN}$, a ratio of 1.25 E. coli per neutrophil, and a final serum con-

TABLE V

Comparison of Bactericidal Activity of Triply-Washed PMN and Sera from Control Subjects and a Patient with C2 Deficiency

\begin{tabular}{|c|c|}
\hline \multirow[b]{3}{*}{$\begin{array}{l}\text { Suspending media; } \\
\text { HBSS plus: }\end{array}$} & Percent of $E$. coli killed in $60 \mathrm{~min}$ \\
\hline & 1.25 Bacteria per cell \\
\hline & $\begin{array}{l}\text { Control } \\
\text { PMN }\end{array}$ \\
\hline Normal pooled serum* & $\left.\right|_{[\mathrm{NS}]} ^{95 \pm 8.1(26) \neq-[\mathrm{NS}] \&-94(4)}$ \\
\hline C2-Deficient serum & $92(6)-[\mathrm{NS}]-91(4)$ \\
\hline C2-Deficient + purified C2 & $94(6) \longrightarrow[N S]-88(4)$ \\
\hline No serum added & $\left.\right|_{[0.05]} ^{1.2 \pm 1.1(14)-[N S]-1.0(4)}$ \\
\hline $\begin{array}{l}\text { Heated pooled serum } \\
\quad\left(56^{\circ} \mathrm{C} \times 30 \mathrm{~min}\right)\end{array}$ & $\left.\right|_{[N S]} ^{14 \pm 12(12)}$ \\
\hline $\begin{array}{l}\text { Heated C2-deficient serum } \\
\left(56^{\circ} \mathrm{C} \times 30 \mathrm{~min}\right)\end{array}$ & $22(3)$ \\
\hline
\end{tabular}

* All serum levels were $4 \%$.

† Mean $\pm 1 \mathrm{SD}(n)$.

$\S[P$ values, NS $>0.05]$. 
centration of $4 \%$. PMN from the patient or control subjects killed the same number of $E$. coli in C2deficient serum as in normal pooled serum. Addition of $\mathrm{C} 2$ reagent to deficient serum did not significantly improve bactericidal activity for either population of PMN. These data indicate that serum factors other than C2 were necessary for optimal bactericidal activity by PMN against this E. coli. Results of studies without added serum, with heated pooled serum, or with heated C2-deficient serum are included (Table V). The serum factors which were responsible for optimal opsonization of $E$. coli are heat labile.

\section{DISCUSSION}

The results of the present investigation clearly document a requirement for $\mathrm{C} 2$ in the optimal killing of $S$. aureus by human PMN. The specificity of this need for C2 was confirmed by showing that reconstitution of serum specifically deficient in C2 with $\mathrm{C} 2$ reagent restored maximal bactericidal activity. This suggests that opsonization of this strain of staphylococcus has a major dependence upon the classical pathway of complement activation. This was particularly apparent at the lower ratio of bacterial challenge. Data from the studies of a C2-deficient serum containing heat-stable opsonin indicate that C2 is most necessary for opsonization of $S$. aureus during the preimmune phase of infection. In contrast, the absence of C2 did not influence the bactericidal outcome when $E$. coli was the test organism. This is in agreement with previous reports of the ability of some strains of $E$. coli to activate complement by the alternate pathway (29).

The demonstrable requirement for $\mathrm{C} 2$ in bactericidal action against $S$. aureus may be a factor contributing to increased susceptibility to bacterial infection in patients with selective C2 deficiency. Seven individuals with this defect, including two of our patients, have had recurrent infections with a propensity for bacterial upper respiratory infections $(16,18,19,30-32)$. This association of $\mathrm{C} 2$ deficiency and recurrent infection does not, however, establish a causal relationship. Because of several factors, including the underlying diseases of the patients (33), possible compensatory mechanisms such as complement-independent opsonins, surface phagocytosis $(34,35)$, and the selective requirement for $\mathrm{C} 2$ by only certain bacteria, this point requires further investigation. This will probably involve detailed, prospective study of individual patients and infective organisms isolated from each.

The present findings also demonstrate that alterations in experimental design of in vitro test systems have a significant influence on the results obtained. Modification of the bacteria to neutrophil ratio in these studies produced changes both in absolute levels of bacteria killed and in the proportionate degrees of abnormality produced by the C2 deficiency. With twice-washed control PMN in C2-deficient serum, increasing the bacterial ratio improved the bactericidal activity against $S$. aureus. In this specific situation a defect was demonstrable at 1.25:1 but not at 50:1. It is not clear from the present experiments at what stage of phagocytosis the condition of minimal opsonization is being compensated for by added bacterial challenge. Increasing the number of bacteria to cell contacts may facilitate attachment via the small amount of cell-associated C2 available. It is also possible that attachment and (or) ingestion of the first few bacteria enhances the intrinsic phagocytic ability of the neutrophil rendering it less dependent upon complement opsonization of the bacteria. This activation phenomenum after the initial ingestion may parallel the enhancement of neutrophil bactericidal capability associated with the second and third bacterial ingestion which has been previously reported (36).

It was the use of two well-controlled ratios of bacteria which led to the recognition of the importance of trace amounts of serum components remaining on once or twice-washed PMN. In these studies, trace amounts of C2 on the surface of control PMN had a profound influence on bactericidal effectiveness in the face of suboptimal opsonization from the media. The amount of $\mathrm{C} 2$ remaining with control PMN progressively decreased as a function of the number of times the cells were washed, and paralleled a declining bactericidal activity in the absence of media opsonins. These findings indicate that the bactericidal action of twice-washed control cells in C2-deficient serum was due to $\mathrm{C} 2$ which remained on the cells. Moreover, they emphasize the necessity for awareness of possible residual serum components on surfaces of phagocytes in the design and interpretation of studies of opsonization.

\section{ACKNOWLEDGMENTS}

The authors gratefully acknowledge Dr. Alfred F. Michael for providing rabbit anti-human C2 and his critical guidance. Ms. Jonalyn Kunce performed the bactericidal assays and Ms. Kay Townsend conducted the complement studies.

This work was supported in part by the Minnesota Medical Foundation, Minnesota and American Heart Associations, Minnesota Arthritis Foundation, the Basil O'Connor Starter Research Fund of the National Foundation of the March of Dimes, Twin Cities Diabetes Association, and grants AI-10704, HE-11880, CA-11996, CA-15548, CA-08832, and HL-17132-1 of the National Institutes of Health.

\section{REFERENCES}

1. Wright, A. E., and S. R. Douglas. 1903. An experimental investigation of the role of blood fluids in connection with phagocytosis. Proc. R. Soc. Lond. B. Biol. Sci. 72: $357-362$. 
2. Ward, H. K., and J. F. Enders. 1933. An analysis of the opsonic and trophic action of normal and immune sera based on experiments with the pneumococcus. $J$. Exp. Med. 57: 527-547.

3. Cohn, Z. A., and S. I. Morse. 1959. Interactions between rabbit polymorphonuclear leukocytes and staphylococci. J. Exp. Med. 110: 419-443.

4. Nelson, R. A., Jr., and J. Lebrum. 1956. The requirement for antibody and complement for in vitro phagocytosis of starch granules. J. Hyg. 54: 8-19.

5. Hirsch, J. G., and A. B. Church. 1960. Studies of phagocytosis of group A streptococci by polymorphonuclear leukocytes in vitro. J. Exp. Med. 111: 309-322.

6. Slopék, S., K. Grzybek-Hryncervicz, and J. Ladosy. 1962. The role of complement and natural antibodies in the process of phagocytosis. Arch. Immunol. Ther. Exp. 10: 503-516.

7. Hirsch, J. G., and B. Strauss. 1964. Studies on heatlabile opsonin in rabbit serum. J. Immunol. 92: 145154.

8. Smith, M. R., and W. B. Wood, Jr. 1969. Heat labile opsonins to pneumococcus. I. Participation of complement. J. Exp. Med. 130: 1209-1227.

9. Wheat, L. J., D. W. Humphreys, and A. White. 1974. Opsonization of staphylococci by normal human sera: the role of antibody and heat-labile factors. J. Lab. Clin. Med. 83: 73-78.

10. Stiffel, C., G. Biozzi, D. Mouton, Y. Bouthillier, and C. Decreusefohd. 1964. Studies of phagocytosis of bacteria by the reticuloendothelial system in a strain of mice lacking hemolytic complement.J. Immunol. 93: 246-249.

11. Gigli, I., and R. A. Nelson, Jr. 1968. Complement dependent immune phagocytosis. I. Requirements for C'1, C'4, C'2, and C'3. Exp. Cell Res. 51: 45-67.

12. Johnston, R. B., Jr., M. R. Klemperer, C. A. Alper, and F. S. Rosen. 1969. The enhancement of bacterial phagocytosis by serum. The role of complement components and two cofactors. J. Exp. Med. 129: 1275-1290.

13. Jasin, H. E. 1972. Human heat labile opsonins: evidence for their mediation via the alternate pathway of complement activation. J. Immunol. 109: 26-31.

14. Johnson, F. R., V. Agnello, and R. C. Williams, Jr. 1972. Opsonic activity in human serum deficient in C2. J. Immunol. 109: 141-145.

15. Stossel, T. P., C. A. Alper, and F. S. Rosen. 1973. Serumdependent phagocytosis of paraffin oil emulsified with bacterial lipopolysaccharide. J. Exp. Med. 137: 690-705.

16. Friend, P., J. E. Repine, Y. Kim, C. C. Clawson, and A. F. Michael. 1975. Deficiency of the second component of complement (C2) with chronic vasculitis. Ann. Intern. Med. 83: 813-816.

17. Friend, P. S., B. S. Handwerger, Y. Kim, A. F. Michael, and E. J. Yunis. 1975. C2-deficiency in man. Genetic relationship to a mixed lymphocyte reaction determinant (7a*). Immunogenetics. 2: 569-576.

18. Glovsky, M. M., G. Opelz, and P. I. Terasaki. 1976. Genetic, opsonic, and bactericidal studies in a C2 deficient family. Clin. Res. 24: 327A. (Abstr.)

19. Day, N. K., H. Geiger, R. McLean, A. Michael, and R. A. Good. 1973. C2 deficiency. Development of lupus erythematosus. J. Clin. Invest. 52: 1601-1607.

20. Mayer, M. M. 1961. Procedure for titration of complement components with $R_{1}, R_{2}, R_{3}$, and $R_{4}$. In Experimental Immunochemistry. E. A. Kabat, and M. M. Mayer, editors. Charles C. Thomas, Publisher, Springfield, Ill. $162-165$.

21. Nelson, R. A., Jr., J. Jensen, I. Gigli, and N. Tamura. 1966. Methods for the separation, purification, and measurement of nine components of hemolytic complement in guinea pig serum. Immunochemistry. 3: 111-135.

22. McLean, R. H., and A. F. Michael. 1973. Properdin and C3 proactivator: alternate pathway components in human glomerulonephritis. J. Clin. Invest. 52: 634-644.

23. Polley, M. J., and H. J. Müller-Eberhard. 1968. The second component of human complement: its isolation, fragmentation by C'l esterase, and incorporation into C'3 convertase. J. Exp. Med. 128: 533-551.

24. Repine, J. E., J. G. White, C. C. Clawson, and B. M. Holmes. 1974. Effects of phorbol myristate acetate on the metabolism and ultrastructure of neutrophils in chronic granulomatous disease. J. Clin. Invest. 54: 83-90.

25. Clawson, C. C., and J. E. Repine. 1976. Quantitation of the maximal bactericidal capability in human neutrophils. J. Lab. Clin. Med. 88: 316-327.

26. Miyakawa, Y., T. Sekine, K. Schimada, and K. Nishioka. 1969. High efficiency of SAC1 ${ }^{\mathrm{gP}} 4^{\mathrm{gp}} 2^{\mathrm{gp}}$ conversion to $\mathrm{S}^{*}$ with EDTA-treated rat serum. J. Immunol. 103: 374377.

27. Opferkuch, W., H. J. Rapp, H. R. Colten, and T. Borsos. 1971. Immune hemolysis and the functional properties of the second (C2) and fourth (C4) components of complement. III. The hemolytic efficiency of human and guinea pig C2 and C4. J. Immunol. 106: 927-931.

28. Borsos, T., H. J. Rapp, and M. M. Mayer. 1961. Studies on the second component of complement. I. The reaction between EAC'1,4 and C'2: evidence on the single site mechanism of immune hemolysis and determination of C'2 on a molecular basis. J. Immunol. 87: 310-325.

29. Morrison, D. C., and L. F. Kline. 1977. Activation of the classical and properdin pathways of complement by bacterial lipopolysaccharides (LPS). J. Immunol. 118: $362-368$.

30. Agnello, C., M. M. E. De Bracco, and H. G. Kunkel. 1972. Hereditary $\mathrm{C} 2$ deficiency with some manifestations of systemic lupus erythematosus. J. Immunol. 108: 837-840.

31. Sussman, M., J. H. Jones, J. D. Almeida, and P. J. Lachmann. 1973. Deficiency of the second component of complement associated with anaphylactoid purpura and the presence of mycoplasma in the serum. Clin. Exp. Immunol. 14: 531-539.

32. Osterland, C. K., L. Espinoza, L. P. Parker, and P. H. Schur. 1975. Inherited C2 deficiency and systemic lupus erythematosus: studies on a family. Ann. Intern. Med. 82: $323-328$

33. Glass, D., D. Raum, D. Gibson, J. S. Stillman, and P. H. Schur. 1976. Inherited deficiency of the second component of complement. Rheumatic disease associations. J. Clin. Invest. 58: 853-861.

34. Wood, W. B., Jr., and M. R. Smith. 1947. Intracellular surface phagocytosis. Science (Wash. D. C.). 106: 86-87.

35. Smith, M. R., and W. B. Wood, Jr. 1958. Surface phagocytosis. Further evidence of its destructive action upon fully encapsulated pneumococci in the absence of typespecific antibody. J. Exp. Med. 107: 1-12 (and plate 1).

36. Melly, M. A., J. B. Thomison, and D. E. Rogers. 1960. Fate of staphylococci within human leukocytes. J. Exp. Med. 112: 1121-1130 (and plates 92 and 93). 